ENERGY MEASUREMENT USING A RESONATOR-BASED TIME-OF-FLIGHT SYSTEM

CONF-830311--104

R. C. Pardo, R. N. Lewl ${ }^{\dagger}$, K. W. Johnson and B. Clifft

Argonne National Laboratory, Argonne, IL 60439 *

\title{
DE63 010580
}

\section{Introduction}

A resonant pickup tlme-of-flight system has been developed for the precise measurenent of beam energy at the Argonne Tandem-Linac Accelerator System (ATLAS). The excellent timing characteristics avallable with ATLAS beans ( $t$ ime widths of 100 ps FWHM or better on target) make 1t desirable to design the beam transport systen to be 1sochronous. Therefore, the use of a dispersive magnetic system for energy analysis would require a large amount of bullding space and be unduly expensive if both energy analysis and isochronous transport were required.

The resonant time-of-flight ristem which has been developed has the following advaniages over other potential approaches.

1. The system is non-1nterceptive and nondestructive. The beam phase space is preserved.

2. It is non-despersive. Path length varlations are not introduced into the beaw transport which would reduce the timing resolution.

3. It has a large signal-to-notse ratio when compared to non-resonant beam plck-up techniques.

4. It provides the means to prectsely set the linac energy and, potentlally, to control the energy in a feedback loop if disired.

5. It is less expensive than an equivalent magnetic system.

\section{Inplementation}

The resonant pickup time-of-flight systew consists of two beam-excited resonators, associated electronics to decode the information, a computer Interf $\rightarrow$ ce to the linac PDP $11 / 34$ control computer, and software to analyze the information and deduce the measured bean energy. A schematic overview of the system is shown in Figure 1.

\section{A. Resonators}

The resonant pickups chosen for the system are $\lambda / 2$ hellx resonators. These resonators are tuned to the beam pulse frequency of $48.5 \mathrm{MHz}$ arid are matched to a synchronous particle velocity of $z=0.1$. Each resonator is $0.32 \mathrm{~m}$ long and has an Inner dlaneter of $11.0 \mathrm{~cm}$. The hellcal structure is constructed of 0.64 cm diameter tubing with a major coll diameter of 5.5 $\mathrm{cm}$ and a pltch of $2.31 \mathrm{~cm}$. The resonators are constructed of stainless steel which is plated with alluer to a thickness of one all. This construction approach produces a rugged Inexpensive design with excellent vacuum characteristics.

In a resonant detector, the fleld induced by a beam pulse decays exponentially and is given at time $t$ aftor the pulse by

$$
E(t)=E_{0} e^{-\omega t / Q}
$$

where $\omega=2 \pi f$ and $f$ is the resonant frequency of the

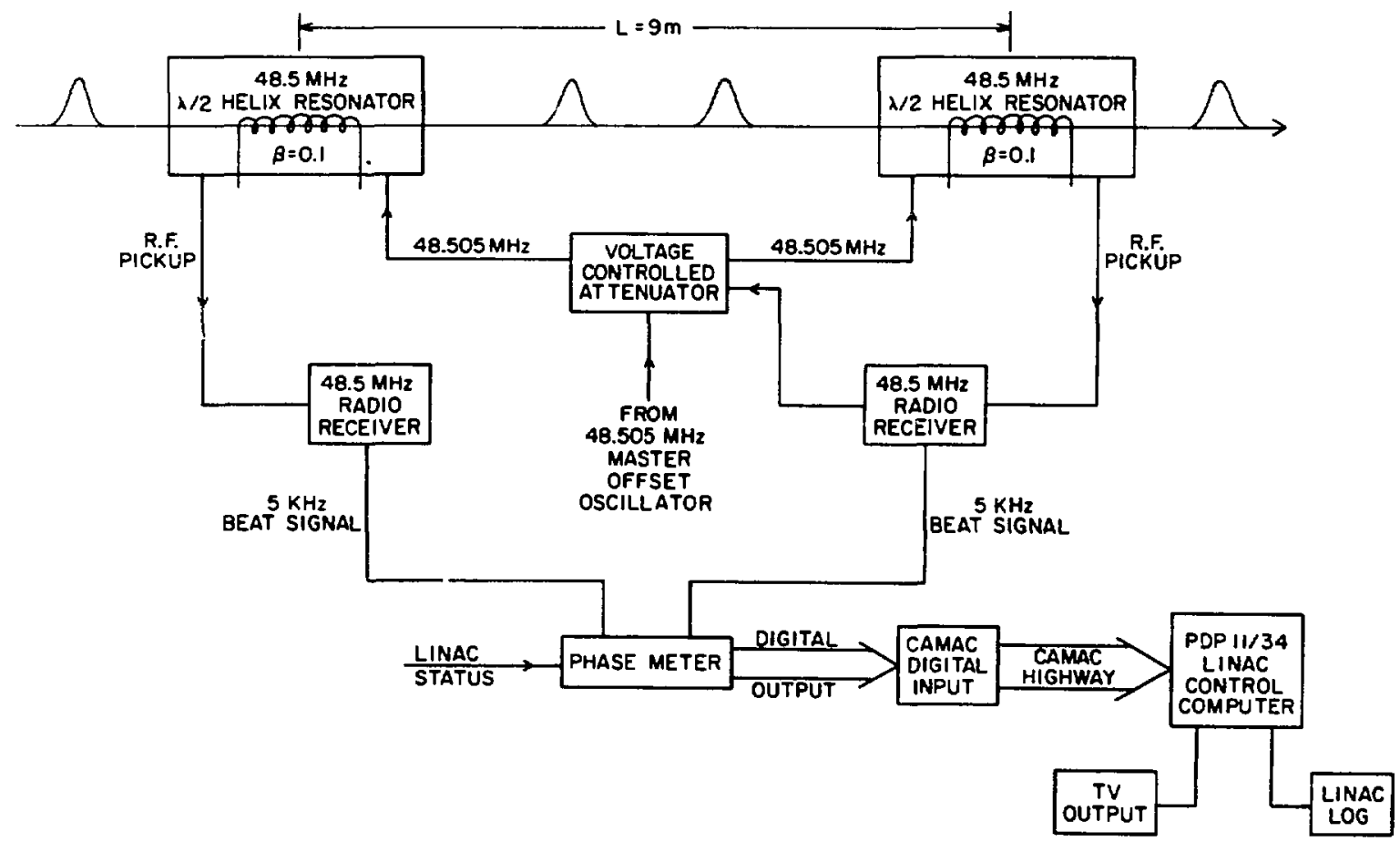

Figure 1. Schematic of Resonant Beam Energy Measurement System. 
detecsor. For these resonatora, the $Q$ 1s approxlately 1900. The induced fleld at any monent in the resonator is an average of any pulses with an averaging the constant of approxiately 6 microseconds ( 300 beat pulses).

\section{B. S1gnal Proceasing}

Each resonator 1s excited by the bean pulaes at a frequency of $48.5 \mathrm{aHz}$ and also by a reference signal with a frequency of $48.5 \mathrm{mHz}+5 \mathrm{kHz}$. The resultant fleld in the resonator has an anplitude modulated component with a $5 \mathrm{kHz}$ frequency. The phase relationship between the bean induced field and the waster oscillator is contained in the phase of the 5 kHz A.M. signal. The relative phase of the beaninduced flelds in the two helix detectors is related to the relative phase of the respective $5 \mathrm{kHz} s$ Ignale $^{\circ}$ by

$$
\theta_{\text {beam }}^{1}-\theta_{\text {beam }}^{2}=\theta_{5 \mathrm{KHz}}^{1}-\theta_{5 \mathrm{KHz}}^{2}+\theta \text {, }
$$

where $\theta$ is a constant of fiet phase.

A schenatic of the elactronlcs used in this systen is shown in Figure 1. The modulated fleld in the sesonator is sent to radio recelver which detects the $5 \mathrm{kHz} s$ ide-band frequency. The phase of that amplifled oignal is aeasured with respert to a simllarly proceased ignal from the recond helix resonator by a comerclal phase meter which is Interfaced to the linac control conputer via the CAMAC highway.

\section{Data Analysis}

The range of particle velocity over which the system must function $150.06 c<B<0.16 c$. For detectors separated by 9 seters, the total transit $t$ tme is auch longer than a ingle $48.5 \mathrm{MHz}$ perlod of 20.6 ns and will vary froe 9 to over 29 perlods. This component of the tine-of-flight inforsation is lost completely by the phase detection system.

There are a nuaber of aethode which could be employed to deteralne the nuaber of perlods in the transit tiae between detectors. The sethod being employed presently is to aseune that the linac bean energy is known frow the tuning data to the accuracy necessary to deternine the number of integer perlods. A aethod which is lese susceptible to error is to deternine the approxinate beas energy based on the magnetic field of a bending aagnet in the besa transport system. Thls wethod will replace the present cechnique shortly. Present experience Indicates that elther of these approaches is acceptable to deternine the approxiaate transit ctme. Of course an unanblguous result would be obtained by installing a third resonator at a distance of less than 1.0 a fron the first resonator.

One additional assunption about the estiated time-of-flight is required. For a phase reading to have unambiguous interpretation, the firac eatiate of the bean tine-of-f11ght must be correct to within $t$ $180^{\circ}$. Th1s assumption allowe a unlque ign to the phase error to be deternined. Here the phase error, $\delta \theta$, is defined as

$$
\$ \theta=\theta_{\text {read }}-\theta_{\text {expected }}
$$

where $\theta$ expected is the phase angle which would be measured for the assumed bean energy.

\section{IIL. Syotes Operation and Sensitivity.}

The energy measutanent oyoten is Installed and functioning on one bean line at the tander-linac. The syeten ylelds phase readinge with typical atablitity of $\pm 0.2^{\circ}$ with an averaging tise of 0.1 asec. For particle velocitles with $B=0.1 \mathrm{c}$, the total filght tive between detectors is $300 \mathrm{~ns}$. Therefore the seneftivity to relative energy changes is

$$
\delta E / E_{0}=2 \delta t / t_{0} \approx 1.0 \times 10^{-4}
$$

The resonant hellx detectors provide a signal strength of approximately 5 WV/nA of bea current (electrical) into 50 ohas. For bean currents below 5 na (electrical), we find an anplituje dependent phase shift wth asnitude of 2.6 degrees at 1 nA of bean current. This reduces the relative energy resolution to $1 \times 10^{-3}$ for beas currents between 1 and $5 \mathrm{nA}$. The observed anplitude-dependent phase ehift is due to the vector addition of a fixed phase nolse source and the actual bean signal. An inproved design of the electronice to increase channel separation is planned which is expected to give Inproved sensitivity to the systen. Another Improvement which is being pursued is the use of apiral resonator, which lo expected to inave better coupling to the bean than the present helix resonator: and therefore yield an iaproved signal-to-nolse ratio.

An Inicial callbration of the systew has bean performed using beass of known energy ( rou the tander accelerator operating with the Ifnac. This callbration 1a based on the callbration of the $90^{\circ}$ analyzing agnet of the tanden accelerator. The preeent absoluce calibration 1s accurate to a value of $\delta E / E \approx 2 \times 10^{-3}$. A nore careful absolute calibration will take place in the near future. To obtain an absolute accuracy approaching $1-2 \times 10^{-4}$ may requite the ability to routinely deternine the distance between the two detectors on a regular basis. This is due to phenonena such as the thernal expansion of concrete which any cause variations in path lfingth of the order of $10^{-4}$ over the course of a year.

In operation of the energy-aeasurenent systed, the IInac computer firat reads the phase angle. The number of $48.5 \mathrm{MHz}$ perlods and the expected phase angle are somputed based on the assuned energy. The difference between the expected phase angle and the read phase angle constitutes a correction to the expected tiwe-of-flight and the corresponding energy for this new flight time is computed. The couputer checks that the accelerator systea is operating properly and deternines that the signal anplitude in the phase detector systen is above a alninua value. If all requitrements are sat lefled, the computed energy 1s displayed on the color TV monitor of the IInac control console. The resulte are also recorded perlodically in the accelerator log.

The eysten will be expanded with the installation of datecting resonatora on other bean lines.

References

1. Hodel 331 , Dranets Englneering Laboratortes, Inc., South Plalnifield, $\mathrm{KJ}$.

Thls research was supported by the U. S. Departent of Energy under Contract W-31-109-Eng-3B.

Decensed. 


\section{DISCLAIMER}

This report was prepared as an account of work sponsored by an agency of the United States Government. Neither the United States Government nor any agency thereof, nor any of their employees, makes any vrarranty, express or implied, or assumes any legal liability or responsibility for the accuracy, completeness, or usefulness of any information, apparatus, product, or process disclosed, or represents that its use would not infringe privately owned rights. Reference herein to any specific commercial product, process, or service by trade name, trademark, manufacturer, or otherwise does not necessarily constitute or imply its endorsement, recommendation, or favoring by the United States Government or any agency thereof. The views and opinions of authors expressed herein do not necessarily state or reflect those of the United States Government or any agency thereof. 